\title{
Effects of ultraviolet irradiation on natural killer cell function in systemic lupus erythematosus
}

\author{
Ola Nived, Ingrid Johansson, Gunnar Sturfelt
}

\begin{abstract}
In vitro irradiation with long wavelength ultraviolet light (UV-A), in clinically relevant dosages, of a natural killer cell line containing cell preparations from 17 control subjects reduced natural killer cell cytotoxicity with the cell line K562 as target. The spontaneous function of natural killer cells from 12 patients with systemic lupus erythematosus (SLE) correlated inversely with the one hour erythrocyte sedimentation rate, but not with glucocorticoid doses. After UV-A exposure, natural killer cells from patients with SLE exert either increased or decreased cytotoxicity, and the direction of change is inversely correlated with the spontaneous natural killer cell function.
\end{abstract}

Natural killer cell activity is reduced in patients with systemic lupus erythematosus (SLE) using a standard K562 cell line as a target, ${ }^{1}$ lymphoblastoid and myeloid cell lines, ${ }^{2}$ and mammary epithelial cell lines. ${ }^{3}$ In patients with SLE a reduction of delayed hypersensitivity is also reported,${ }^{4}$ which is at least partly mediated by natural killer cells. Silvèrman and Cathcard ${ }^{1}$ proposed that the reduced cytotoxicity is due to membrane bound serum inhibitory factors, probably immune complexes. Talal ${ }^{5}$ suggested that antibody dependent cellular cytotoxicity, regarded as the most important cytotoxicity mechanism in SLE and also known to be reduced in SLE due to immune complexes, was in fact an overlapping function with natural killer cells, mediated by similar, if not identical, cell populations.

Photosensitivity induced by short wavelength ultraviolet (UV-B) irradiation is a well documented symptom of SLE, ${ }^{6}$ and general photoimmunology has attracted a great deal of interest. ${ }^{7}$ In solar simulator studies, with a dominance of long wavelength ultraviolet light (UV-A), increased suppressor $\mathrm{T}$ cell activity reducing natural killer cell function has been reported in vivo in normal subjects. ${ }^{89}$ It has also been reported that the in vitro exposure of normal natural killer cells to UV-B radiation inhibits their function by a direct non-lethal effect, and that this inhibition occurs selectively at the postbinding stage of target lysis. ${ }^{10}$ In this work the in vitro effects of irradiation with UV-A light of natural killer cells from patients with SLE have been studied.

\section{Patients and methods}

PATIENTS AND CONTROLS

Twelve patients with SLE fulfilling at least four American Rheumatism Association revised classification criteria $^{6}$ were included in the study. There were two men and ten women, mean age 43 years (range 14-64). Disease activity at the time of blood sampling was assessed and graded with the SLEDAI index, where scores from 0 to 49 are theoretically possible, although in validation studies the range has been from 0 to 14 (Kalunian et al, unpublished data). Treatment with drugs was recorded and routine laboratory tests such as erythrocyte sedimentation rate, white blood cell counts, and complement components $\mathrm{Clq}, \mathrm{C} 3$, and $\mathrm{C} 4$ were performed.

Seventeen healthy hospital staff, five men and 12 women, mean age 37 years (range 18-57), were used as controls. All participants gave informed consent and the SLE study was approved by the ethical committees of the University of Lund.

\section{ISOLATION OF MONONUCLEAR CELLS}

Cells were prepared according to Pross and Maroun, ${ }^{11}$ with the exception of the iron carbonyl addition and the passage over a magnet. Blood samples were collected in heparinised vacuum tubes and $30 \mathrm{ml}$ volumes were layered onto $15 \mathrm{ml}$ of Lymphoprep (Pharmacia, Uppsala, Sweden). ${ }^{12}$ The gradients were centrifuged for 30 minutes at $750 \mathrm{~g}$ at room temperature and the lymphocyte monocyte band at the interface, containing natural killer cells, was removed. The band was washed twice in RPMI 1640 and resuspended in RPMI 1640 containing $10 \%$ fetal calf serum, $50 \mu \mathrm{g} / \mathrm{ml}$ gentamycin, and $2 \mathrm{mM}$ L-glutamine. The mononuclear cells were counted and adjusted to three concentrations $\left(2.5 \times 10^{6}, 1.25 \times 10^{6}\right.$ and $0.625 \times 10^{6}$ viable cells/ml).

\section{TARGET CELL PREPARATION}

The chronic myelogenous leukaemic, HLA negative, and Epstein-Barr free standard cell line K562 was used as the target for natural killer cell activity. ${ }^{13}$ Cells were cultured in suspension (RPMI 1640 containing $10 \%$ fetal calf serum, $50 \mu \mathrm{g} / \mathrm{ml}$ gentamycin and $2 \mathrm{mM} \mathrm{L}$ glutamine) and the cultures were fed three times weekly. For labelling, approximately $10^{6}$ target cells in $0.1 \mathrm{ml}$ of phosphate buffered saline were incubated with $5550 \mathrm{kBq}$ chromium-51 for one hour at $37^{\circ} \mathrm{C}$. The labelled cells were washed three times in medium and resuspended at the appropriate concentration $\left(2 \cdot 5 \times 10^{4}\right.$ cells $\left./ \mathrm{ml}\right)$ to give 2500 cells/well. ${ }^{11}$

\section{ULTRAVIOLET IRRADIATION}

The ultraviolet source was a solar simulator bed (Solana, Motala, Sweden) equipped with 19
S 221 85, Lund, Sweden. Accepted for publication 25 October 1991 
fluorescent tubes (Philips TLK $100 \mathrm{~W}$ ) with an emission spectrum of $295-400 \mathrm{~nm}$ and an effect of $136-166 \mathrm{~W} / \mathrm{m}^{2}$ in the UV-A range and $0.005-0.010 \mathrm{~W} / \mathrm{m}^{2}$ in the UV-B range (National Institute for Radiation Protection, Stockholm, Sweden), determined at $0 \mathrm{~cm}$ distance.

Irradiation of normal cells was studied in a dose response manner and an exposure time of 14 minutes was selected, giving a decrease of cell mediated target lysis from a median of $14.8 \%$ (range $4.5-43 \%$ ) to a median of $1.9 \%$ (range $0-9 \cdot 4 \%$ ) with an effector to target cell ratio of 100:1. Longer exposure times tested did not have any significant further decrease of target cell lysis. The exposure distance chosen, $50 \mathrm{~cm}$, was the shortest possible distance compatible with the requirement of constant temperature at the time given. The mean UV-A effect at this distance was $98 \mathrm{~W} / \mathrm{m}^{2}$ (Waldmann PUVA-meter, Villingen-Schwenningen) and thus the UV-A dose was $82 \cdot 3 \mathrm{~kJ} / \mathrm{m}^{2}$. The cell viability determined with trypan blue exclusion was within the range $96-100 \%$ in all experiments. Control experiments with an ultraviolet filter (Kodak Wratten, gelatin filter No 1A) and ultraviolet longpass filters (Schott glass filters Nos WG320, WG345, GG375, and GG395) were performed.

\section{NATURAL KILLER CELL ASSAY}

The natural killer function was assessed by the chromium release assay with the target cells labelled with chromium-51 incubated for four hours in $5 \%$ carbon dioxide at $37^{\circ} \mathrm{C}$, with three twofold dilutions of effector cells. Each effector to target (ET) ratio was plated in triplicate. The cell mediated lysis (CML) was calculated from the following equation, where CPM ${ }_{\text {test }}$ refers to the counts in the supernatant from wells containing effector cells, $\mathrm{CPM}_{\text {spont }}$ is the spontaneous release without effector cells present, and $\mathrm{CPM}_{\max }$ is the maximum incorporated counts obtained by lysis with detergent ${ }^{11}$

$$
\% \mathrm{CML}=\frac{\mathrm{CPM}_{\text {test }}-\mathrm{CPM}_{\mathrm{sp} \text { w11 }}}{\mathrm{CPM}_{\max }-\mathrm{CPM}_{\mathrm{spont}}} \times 100
$$

\section{DATA ANALYSIS}

Killing at each effector to target ratio was expressed as the mean percentage of target cells lysed during the incubation period. Lytic units

Relative natural killer cell function (RNK) related to SLE disease activity (SLEDAI), erythrocyte sedimentation rate $(E S R)$, and prednisolone dose $(P)$.

\begin{tabular}{|c|c|c|c|c|c|}
\hline Patient No & $\begin{array}{l}R N K-0 \\
(0 \text { min })\end{array}$ & $\begin{array}{l}R N K-14 \\
(14 \mathrm{~min})\end{array}$ & $\begin{array}{l}S L E D A I \\
(14 \cdot 0)\end{array}$ & $\begin{array}{l}E S R \\
(\boldsymbol{m m} / h)\end{array}$ & $\begin{array}{l}P \\
(m g)\end{array}$ \\
\hline $\begin{array}{r}1 \\
2 \\
3 \\
4 \\
5 \\
6 \\
7 \\
8 \\
9 \\
10 \\
11 \\
12\end{array}$ & $\begin{array}{l}0.12 \\
0.13 \\
0.21 \\
0.24 \\
0.32 \\
0.47 \\
0.59 \\
0.74 \\
1.18 \\
1.18 \\
1.47 \\
2.35\end{array}$ & $\begin{array}{l}0.24 \\
0.24 \\
0.07 \\
0.09 \\
1.18 \\
2.37 \\
0.02 \\
0.05 \\
0.44 \\
1.63 \\
0.35 \\
1.47\end{array}$ & $\begin{array}{r}20 \\
6 \\
7 \\
6 \\
2 \\
2 \\
4 \\
0 \\
5 \\
2 \\
11 \\
3\end{array}$ & $\begin{array}{l}62 \\
30 \\
90 \\
40 \\
14 \\
46 \\
17 \\
29 \\
26 \\
24 \\
5 \\
16\end{array}$ & $\begin{array}{l}15 \\
5 \\
0 \\
5 \\
2.5 \\
0 \\
5 \\
7.5 \\
12.5 \\
3.75 \\
8.75 \\
7.5\end{array}$ \\
\hline $\begin{array}{l}\text { Correlation } \\
\text { with RNK-0 }\end{array}$ & 二 & - & $\begin{array}{l}\mathrm{r}_{\mathrm{s}}=-0.39 \\
\mathrm{NS}\end{array}$ & $\begin{array}{l}r_{s}=-0.71 \\
p<0.01\end{array}$ & NS \\
\hline
\end{tabular}

were calculated using a linear regression analysis that incorporated the percentage of chromium released at each of three effector to target ratios. Results are expressed as the number of lytic units per $10^{7}$ effector cells $\left(\mathrm{LU}_{20} / 10^{7}\right) ; \mathrm{LU}_{20}$ represents the number of effector cells required to lyse $20 \%$ of the target cells $\left(10^{3}\right)$. To correct for day to day variations at least one or two of the 17 controls were included in each experiment and the percentage cytotoxicity for each patient was compared with the normal control value. To standardise the comparison between different experiments the results are also presented as relative natural killer cell function (RNK). The RNK value was calculated according to the following equation: ${ }^{11}$

RNK = individual LU on day of assay/mean LU for all controls

Only non-parametric statistical tests were used; for two independent samples the MannWhitney $U$ test and for related samples the Wilcoxon matched pairs signed rank test. Correlation was calculated with Spearman's rank test. ${ }^{14} \mathrm{p}$ Levels less than 0.05 were considered significant.

\section{Results}

There was no difference in lytic activity between the groups of patients and controls before irradiation of cells, but four individual patients had a lower RNK value than any of the controls. All of these four patients had active disease; one young women (patient No 1) had cutaneous vasculitis, cranial nerve manifestations, and new rash; one man (patient No 2) had new onset proteinuria; another young women (patient No 3) had new rash and fever; and patient No 4, a man, had pronounced polyarthritis (table).

After irradiation lytic activity of natural killer cells was decreased in the controls $(p<0.005)$ but not in the patients. Lytic activity was increased in five patients, whereas it was decreased in all controls. Two of these five patients were among the four with a low initial RNK value (patients Nos 1 and 2), whereas the other three patients (patients Nos 5, 6 and 10) were all clinically inactive, but had low complement concentrations (table). The amount of irradiation induced change of natural killer cell function also differed when patients and controls were compared ( $p<0.025$, fig 1 ).

The ultraviolet wavelengths responsible for the decrease of natural killer cell function seen in controls were UV-A, as shown with the longpass ultraviolet filters (fig 2).

Correlations were calculated between the RNK value, before and after irradiation, and the disease activity index, glucocorticoid dosage, erythrocyte sedimentation rate, and levels of $\mathrm{Clq}, \mathrm{C} 3$, and C4. Neither of the complement components correlated with the RNK values. A trend towards an inverse correlation was found between disease activity and the RNK value before irradiation (table).

One patient (No 9) was sequentially analysed through a flare of disease activity and an inverse 
A

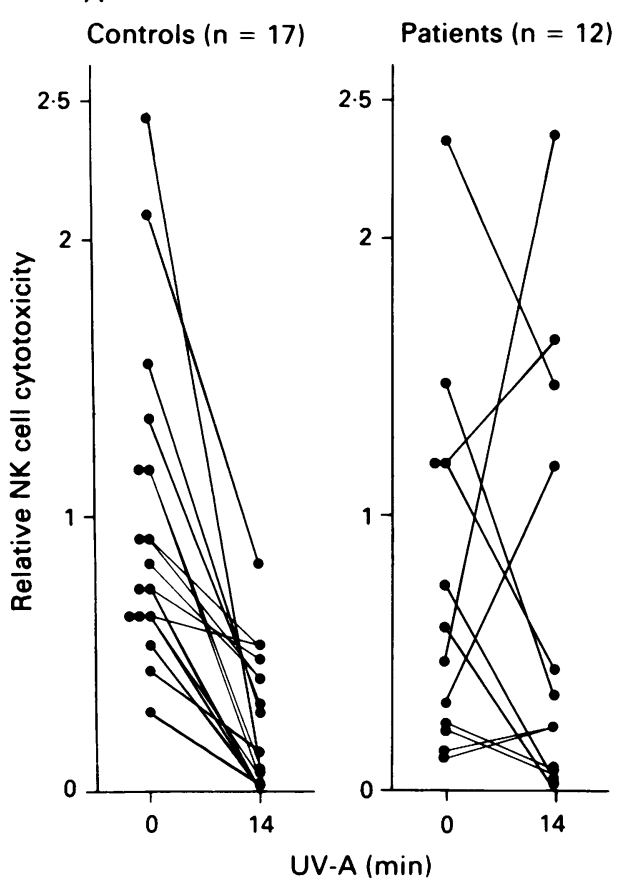

B

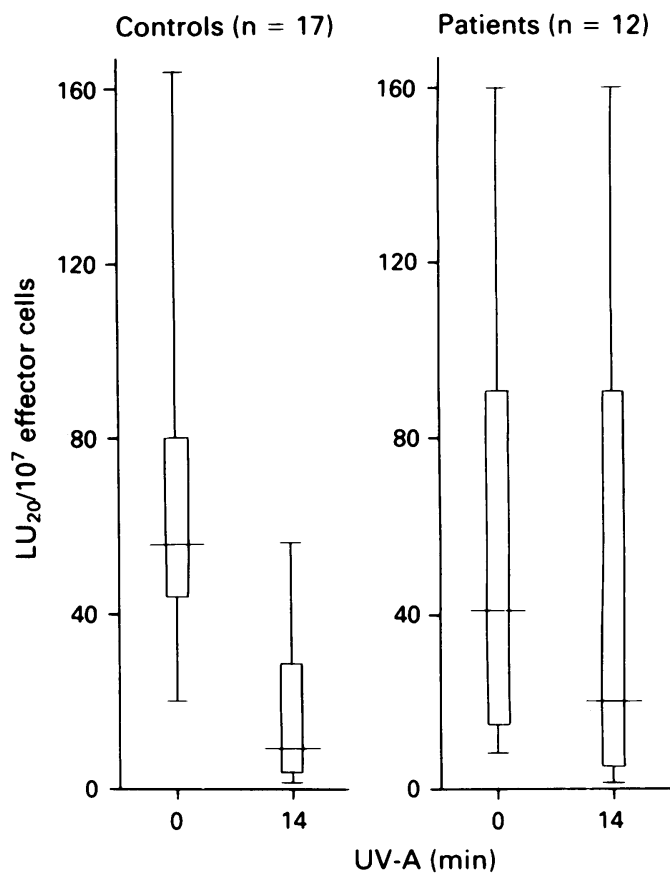

Figure 1 In vitro natural killer (NK) cell function in control subjects and patients with SLE before and after 14 minutes in vitro $U V-A$ irradiation, expressed as individual relative natural killer cell cytotoxicity in $(A)$, and as lytic units $(L U)$ in groups in $(B)$. Bars indicate median, 25th and 75th centiles, and range.

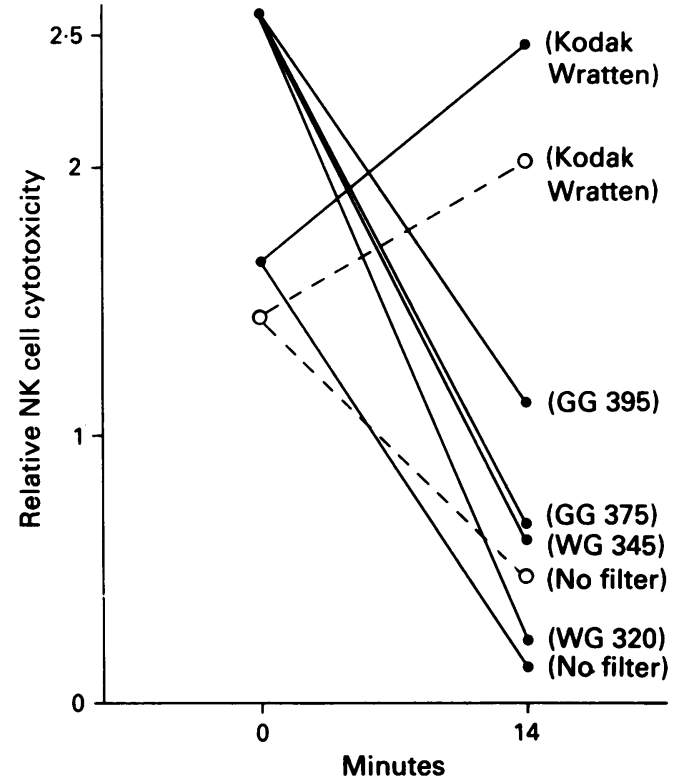

Figure 2 Relative in vitro natural killer $(N K)$ cell cytotoxicity, before and after 14 minutes in vitro $U V-A$ irradiation, in the presence or absence of ultraviolet longpass filters. Filter numbers indicate the longpass cutoff wavelengths. The Wratten filter transmission is $59 \%$ at $400 \mathrm{~nm}, 76 \%$ at $410 \mathrm{~nm}, 82 \%$ at $420 \mathrm{~nm}$, and $84 \cdot 6 \%$ at $430 \mathrm{~nm}$.

relationship between the RNK value and disease activity was noted (fig 3 ).

The difference in the RNK value, before and after irradiation, in patients with SLE tended to increase if the starting value was low and to decrease if the RNK value before irradiation was in the normal range (table).

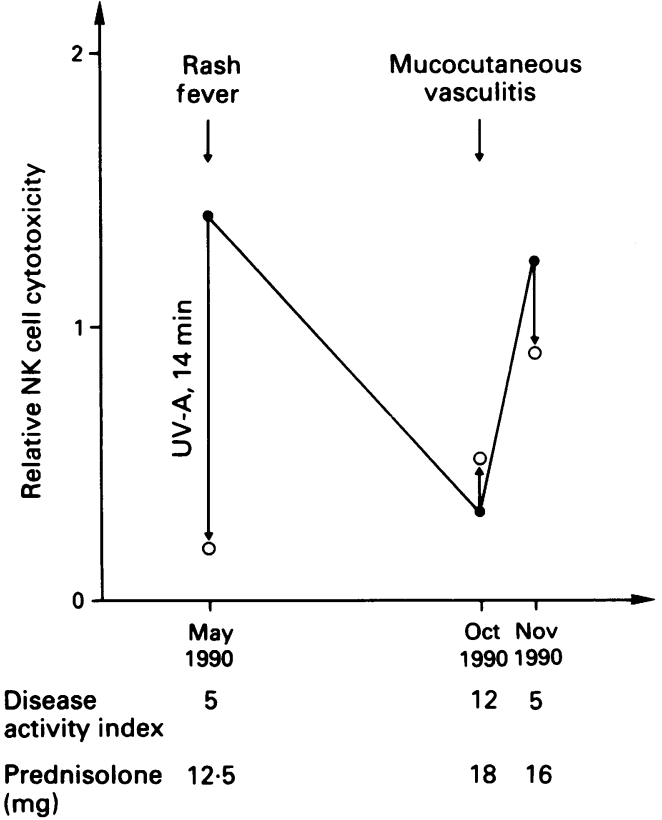

Figure 3 Sequential relative natural killer $(N K)$ cell in vitro cytotoxicity, before $(O)$ and after (O) 14 minutes in vitro UV-A irradiation, of natural killer cells from a patient with SLE with varying disease activity (disease activity index).

\section{Discussion}

This study shows that 14 minutes of irradiation with ultraviolet light reduces natural killer cell function in vitro, and that this reduction is mediated by the long wavelength, low energy ultraviolet spectrum, or UV-A. A parallel in vivo observation has been reported by Hersey and coworkers, who found that repeated in vivo 
exposures of normal subjects to UV-A induced a reduced natural killer cell activity up to 14 days after exposure. ${ }^{89}$ Interestingly, this inhibitory pattern was most pronounced in normal donors, whereas only natural killer cells from some patients with SLE reacted as controls. In contrast, five of 12 patients with SLE increased their RNK value when cells were exposed to UV-A irradiation.

We confirmed the previous observation that the RNK value is reduced in active SLE, ${ }^{1}$ at least if an increased erythrocyte sedimentation rate is accepted as an indicator of active disease. Our results suggest that patients with a low RNK value are those who react with an increased RNK value on exposure to ultraviolet irradiation. The fact that the RNK value in our patients as a group did not differ from the controls before irradiation is probably due to the proportion of patients included with inactive disease. No influence of treatment, especially glucocorticoids, could be detected, but the doses were in all instances below those previously reported to reduce the $\mathrm{RNK}$ value. ${ }^{15}$ One patient treated with azathioprine was among those with a reduced RNK value, which is in accordance with the inhibited maturation of natural killer cells reported in patients with rheumatoid arthritis receiving this drug. ${ }^{16}$ The natural killer cells from this patient with SLE also increased their lytic activity after UV-A irradiation.

The UV-A radiation reaching the dermal capillaries of a subject on the earth's surface on a sunny day is about $25 \mathrm{~W} / \mathrm{m}^{2}$, assuming a tissue transmittance of $10 \% .{ }^{17}$ Thus our UV-A irradiation dosage corresponds to one hour in the sun under similar conditions. The exposure therefore seems to be clinically appropriate, but caution is needed in interpreting data based on circulating natural killer cells, even if some precursors travel through the circulation before homing to their target tissue. ${ }^{18}$

The mechanism behind reduced natural killer cell function in active SLE is not known, but serum factors, perhaps blocking immune complexes, ${ }^{1}$ antibodies to lymphocytes, ${ }^{19}$ or reduced interleukin 2 mediated signal transduction $^{20}$ are likely to play a part. A high proportion of immature, circulating natural killer cells are found in patients with SLE and multiple sclerosis, ${ }^{21}$ and natural killer cells in patients with SLE are less responsive to interferon. ${ }^{22}$ Interferon $\gamma$, also produced in natural killer cells, increases the lytic activity of normal natural killer cells, but a negative feedback through increased $F c$ receptor presentation on the cell surface by interferon $\gamma$ has also been shown. ${ }^{23}$ As interleukin $2 "$ timulates interferon production, the low levels of interleukin 2 in serum samples from patients with active SLE ${ }^{24}$ also might influence natural killer cell function.

Hypothetically, a reduction of interferon activity induced by UV-A would lead to reduced spontaneous activation of natural killer cells from normal donors. In the patients with SLE with increased natural killer cells, ${ }^{25}$ expressing high $\mathrm{Fc}$ receptor densities on the cell membrane, and $\mathrm{Fc}$ bound immune complexes, all downregulating the RNK value, a reverse scenario seems possible. Hypothetically, UV-A might release the blocking immune complexes from Fc binding and thereby increase the RNK value.

Photoactivation of cutaneous SLE has long been known to occur, ${ }^{26}$ as has the activation of systemic manifestations. ${ }^{27} 28$ The importance of UV-A in this respect is poorly documented, but it has been suggested by an anecdote of exposure to ordinary fluorescent tubes. ${ }^{29}$ It is too early to say if the increase in the RNK value observed in vitro in some of our patients with SLE has any bearing on the clinical disease; however, the selective in vitro effects of UV-A on natural killer cells in SLE merits further investigation.

Supported by grants from Swedish Medical Research Council (grant number 3583), Alfred Osterlunds Stiftelse, Greta och Johan Kocks Stiftelser, Konung Gustaf V:s 80 årsfond, Lunds Sjukvărdsdistrikt, Stiftelsen Bistănd át Vanföra i Skăne, The Medical Faculty of the University of Lund and Crafoordska Medical Fac
Stiftelsen.

1 Silverman S L, Cathcart E S. Natural killing in systemic lupus erythematosus: inhibitory effects of serum. Clin Immunol Immunopathol 1980; 17: 219-26.

2 Hoffman T. Natural killer function in systemic lupus erythematosus. Arthritis Rheum 1980; 23: $30-5$.

3 Fitzharris P, Alcocer J, Stephens H A F, Knight R A, Snaith $M$ L. Insensitivity to interferon of NK cells from patients with systemic lupus erythematosus. Clin Exp Immunol 1982; 47: 110-8.

4 Tartof D, Yung C W, Curran J J, Livingston C, Thalji Z. Cells that mediate NK like cytotoxicity are present in the human delayed type hypersensitivity response. Clin Exp human delayed type hypersen

5 Talal $\mathrm{N}$. Interferon and natural killer cells in rheumatic diseases. In: Gupta S, Talal N, eds. Immunology of rheumatic diseases. New York and London: Plenum Medical, 1985.

6 Tan E M, Cohen A S, Fries J F, et al. The 1982 revised criteria for the classification of systemic lupus erythematosus. Arthritis Rheum 1982; 25: 1271-7.

7 Parrish J A. Photobiology and immunology. In: Parrish J A, ed. Effects of $U V$ radiation on the immune system. Skillman, NJ: Johnson \& Johnson, 1983

8 Hersey $P$, Bradley $M$, Hasic E, Haran G, Edwards A, McCarthy $W$ H. Immunological effects of solarium exposure. Lancet 1983; i: 545-8.

9 Hersey P, MacDonald M, Henderson C, et al. Suppression of natural killer cell activity in humans by radiation from solarium lamps depleted of UVB. F Invest Dermatol 1988; 90: $305-10$

10 Elmets C A, Larsen K, Urda G A, Schacter B. Inhibition of postbinding target cell lysis and of lymphokine-induced enhancement of human natural killer cell activity by in vitro exposure to ultraviolet B radiation. Cell Immunol 1987; 104: 47-58.

11 Pross H F, Maroun J A. The standardization of NK cell assays for use in studies of biological response modifiers. f Immunol Methods 1984; 68: 235-49.

12 Böyum A. Separation of leucocytes from blood and bone marrow. Scand f Lab Clin Invest 1968; 21 (suppl 97).

13 Lozzio C B, Lozzio B B. Cytotoxicity of a factor isolated from human spleen. $\mathcal{f}$ Natl Cancer Inst 1973; 50: 535-40.

14 Siegel S. Nonparametric statistics for the behavioral sciences. New York, Toronto, London: McGraw-Hill, 1956.

15 Pedersen B K. Modulation of natural killer cell activity in patients with immuno-inflammatory diseases. Dan Med Bull 1988; 35, 315-22.

16 Cseuz R, Panayi G S. The inhibition of NK cell function by azathioprine during treatment of patients with rheumatoid arthritis. Br $\mathcal{F}$ Rheumatol 1990; 29: 358-62.

17 Becker N C, Crockett R S, Valenzeno D P, Abdou N I. Effect of in vitro ultraviolet radiation on the binding capacity of anti-DNA and DNA in systemic lupus erythematosus. F Rheumatol 1989; 16: 773-6.

18 Kutteh W H, Koopman W J, Conley M E, Egan M L, Mestecky J. Production of predominantly polymeric IgA by human peripheral blood lymphocytes stimulated in vitro with mitogens. F Exp Med 1980; 152: 1424-9.

19 Goto M, Tanimoto K, Horiuchi Y. Natural killer cell mediated cytotoxicity in systemic lupus erythematosus: suppression by antilymphocyte antibody. Arthritis Rheum 1980; 23: 1274-81.

20 Sirianni M C, Tagliaferri F, Aiuti F. Pathogenesis of natural killer cell deficiency in AIDS. Immunol Today 1990; 11 : 81-2.

21 Egan M L, Mendelsohn S L, Abo T, Balch C M. Natural killer cells in systemic lupus erythematosus. Abnormal numbers and functional immaturity of $\mathrm{HNK}_{-1}^{+}$cells. Arthritis Rheum 1983; 26: 623-9.

22 Sibbit W L, Froelich C J, Bankhurst A D. Abnormal interferon modulation of natural cytotoxicity in systemic 
lupus erythematosus. Relation to suppressive serum factors. Arthritis Rheum 1983; 26: 1452-9.

23 Itoh K, Inoue M. Kataoka S, Kumagai K. Differential effect of interferon expression of IgG- and IgM-Fc receptors on human lymphocytes. F Immunol 1980; 124: 2589-95.

24 Johansen P B, Nässberger L, Alves M A, Nived (), Sturfelt G. Soluble interleukin-2 receptor in systemic lupus erythematosus--relation to disease activity and kidney function. Clin Exp Rheumatol. In press.

25 Herberman R B, Ortaldo J R, Djeu J Y, et al. Role of interferon in regulation of cytotoxicity by natural killer cell and macrophages. Ann NY Acad Sci 1980; 350: 63-71.
26 Rasch C. Effect of light on skin and skin diseases. Proc Roy Soc Med 1926; 20: 1-20.

27 Epstein J H, Tuffanelli D L. Photoreactions in lupus erythematosus. In: Dubois E L, ed. Lupus erythematosus. Los Angeles: University of Southern California Press, 1974

28 Sturfelt G, Nived $O$. Clinical inconsistency, benign course and normal employment rates in unselected systemic lupus erythematosus. Clin Exp Rheumatol 1985; 3: 303-10.

29 Martin L, Chalmers I M. Photosensitivity to fluorescent light in a patient with systemic lupus erythematosus. 7 Rheumain a patient with systemi 